\title{
Demonstration and laboratory complex for the production of heat energy using sources of unconventional and waste energy
}

\author{
$L V$ Plotnikova $^{1, *}, A A$ Faizullin $^{1}, A S$ Gavrilov $^{1}$ and $N M$ Hacıbalayev $^{2}$ \\ ${ }^{1}$ Kazan State Power Engineering University, 51 Krasnoselskaya Street, Kazan, Russia \\ ${ }^{2}$ Sumgait State University, 43rd block, AZ5007, Sumgait, Azerbaijan
}

\begin{abstract}
The description of the work of a laboratory unit for the production of thermal energy that simulates the use of solar energy and the use of wastewater energy is presented. The installation includes a heat pump, solar collector and waste water tank. Presents options forwiring elements of the unit.
\end{abstract}

\section{Introduction}

Demonstration and laboratory complex Viessmann is designed to release thermal energy from a source of lowpotential thermal energy to a consumer with a higher temperature. As a source of low-potential thermal energy, the installation simulates unconventional energy and waste energy $[1,2]$ of enterprises - solar energy and wastewater energy, respectively. As a consumer is considered a hot water system of the building. The basis of the installation that increases the potential of the energy source is a heat pump. This installation for the preparation of hot water supply is located at the Department of Industrial Heat Power Engineering and Heat Supply Systems of Kazan State Power University in the auditory B-214 (Figure 1).

The basic configuration of the laboratory installation (Figure 1 (a)) includes a heat pump with a Vitosolic 200 control unit (Figure 1 (b)), a cubic tank, 2 buffer tanks, a solar collector, a Vitosolic solar control system, Wilo and Grundfos circulation pumps, instrumentation equipment. The main site of the collection of lowpotential thermal energy is the solar collector.

Two options were considered for switching on the heat pump into the laboratory unit for the production of heat energy in order to increase the energy potential of the source [ $1-3]$; their schemes are shown in the figures below.

\section{Installation sheme, simulating the use of wastewater energy}

One of the proposed configurations of the laboratorydemonstration complex is an installation that simulates the use of wastewater energy for hot water supply [4] ("water-to-water" type) (Figure 2). The use of

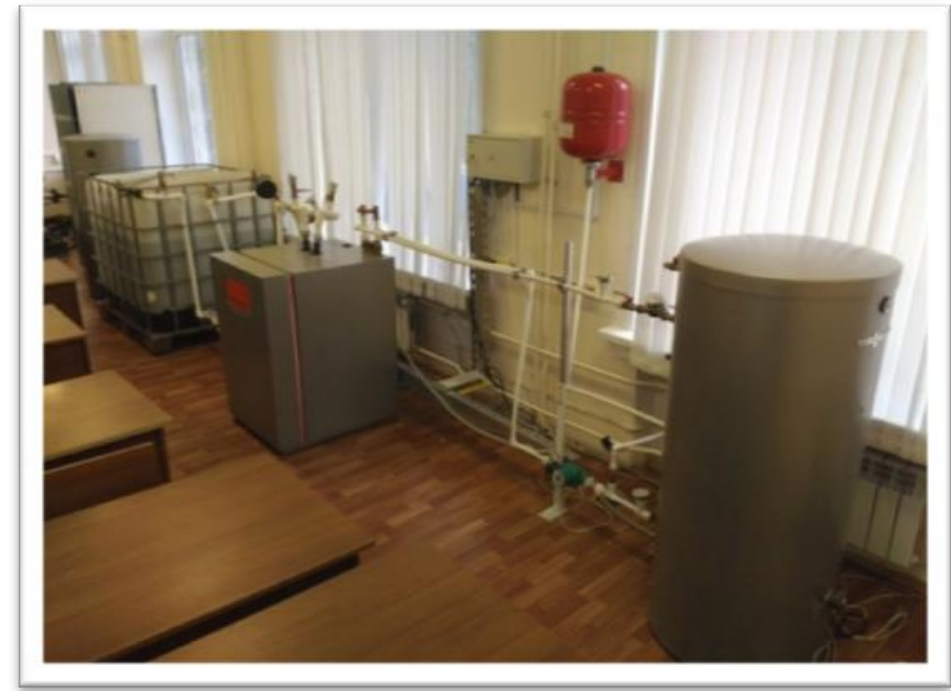

a)

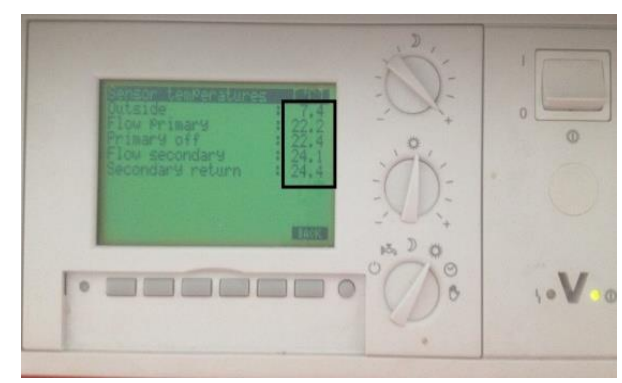

b)

\footnotetext{
*Corresponding author: mikhailovalv@ mail.ru
}

(C) The Authors, published by EDP Sciences. This is an open access article distributed under the terms of the Creative Commons Attribution License 4.0 


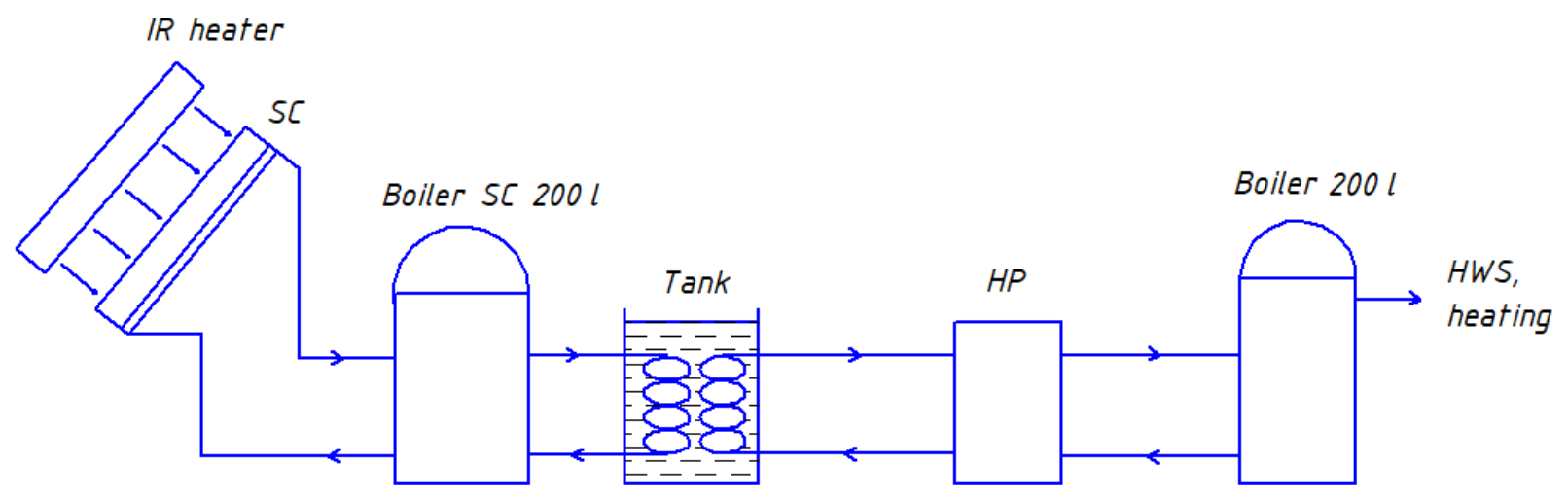

Fig. 2. Installation diagram with the inclusion of a heat pump and solar collector: IR heater - infrared heater; SC - solar collector; Tank - cubic tank with simulated wastewater; HP - heat pump; HWS - hot water supply.

wastewater energy is important, because they have significant resource volumes $[5-7]$ and have a permissible temperature for use in a heat pump. The temperature of wastewater is much higher than the temperature of geothermal energy, which indicates the possibility of using more heat per unit volume of the energy source [2]. The simulated wastewater is located in the tank of the laboratory unit, and its heating to the temperature of the real wastewater is provided by a circuit with a solar collector. The installation is complemented by an infrared heater to simulate solar energy.

The installation (Figure 2) works as follows. In the solar collector Vitosol 100-F with an area of $2.51 \mathrm{~m} 2$, the water of the circulation circuit is heated by radiation from an infrared heater BIH-L-3.0. The heated water from the boiler of the Vitocel 100-E solar collector is sent to a vat tank. In it, tubes with a coolant pass through the entire internal volume of the tank and maintain the required temperature of the water in the tank. Next, there is a heat exchange between the water in the tank and the water in the tubes of the Vitocal 300-G heat pump. The heated water enters the housing of the heat pump, it gives off heat to the intermediate coolant in the evaporator of the heat pump. As the intermediate heat carrier R407C freon is used. Next, the waste chilled water is returned to the tank to raise the temperature. The evaporated freon is compressed in a heat pump compressor in order to increase the energy potential of this intermediate coolant. Next, high-potential freon in the heat pump condenser transfers heat to the water from another installation circuit, which is sent to the Vitocell 100 -E buffer tank and then goes to the needs of hot water supply HWS.

To achieve the required temperature of hot water for the needs of HWS of $55{ }^{\circ} \mathrm{C}$ in this laboratory installation, a heat source of $38^{\circ} \mathrm{C}$ is required. This was confirmed experimentally (table 1 ). The temperature of the simulated water in the bottom of the tank varied from $20{ }^{\circ} \mathrm{C}$ to $40{ }^{\circ} \mathrm{C}$, while the readings of the primary and secondary sources of heat were taken from the control panel of the heat pump (Figure 1 (b)).
Table 1. Experimental indicators of coolant temperatures.

\begin{tabular}{|c|c|}
\hline $\begin{array}{c}\text { The temperature of the } \\
\text { source }- \text { of the "waste water" } \\
\text { in the tank, }{ }^{\circ} \mathbf{C}\end{array}$ & $\begin{array}{c}\text { Experimental water } \\
\text { temperature for HWS, } \\
{ }^{\circ} \mathbf{C}\end{array}$ \\
\hline 20 & 45 \\
\hline 25 & 48 \\
\hline 30 & 51 \\
\hline 35 & 53 \\
\hline 38 & 55 \\
\hline 40 & 56 \\
\hline
\end{tabular}

As a result, it can be concluded that the use of wastewater in this installation configuration will not provide the desired temperature HWS. The temperature of wastewater at enterprises varies between $18-30{ }^{\circ} \mathrm{C}$, which in this installation gives the temperature on the HWS within $45-51{ }^{\circ} \mathrm{C}$. This is due to the significant loss of thermal energy during its transfer insid the tank and the presence of several heat exchange circuits. In addition, in this scheme (Figure 2), solar energy is used only for heating water that simulates wastewater, and it is not possible to estimate the efficiency of solar energy use in heat pump installations. In this regard, it was decided to upgrade the original inclusion scheme (Figure 3).

\section{Installation sheme, simulating the use of solar energy and wastewater energy}

The upgraded configuration of the laboratorydemonstration complex is an installation that simulates the simultaneous use of solar energy and wastewater energy for hot water supply ("air - water" type and "water - water" type) (Figure 3).

So, it was experimentally revealed that to achieve the required temperature of hot water for the needs of HWS of $55^{\circ} \mathrm{C}$ in this laboratory installation, a heat source of $38^{\circ} \mathrm{C}$ is required. In this regard, it is proposed to connect the solar collector directly to the heat pump, bypassing the cube capacity. The solar collector provides the required temperature for the heat pump evaporator at 38 


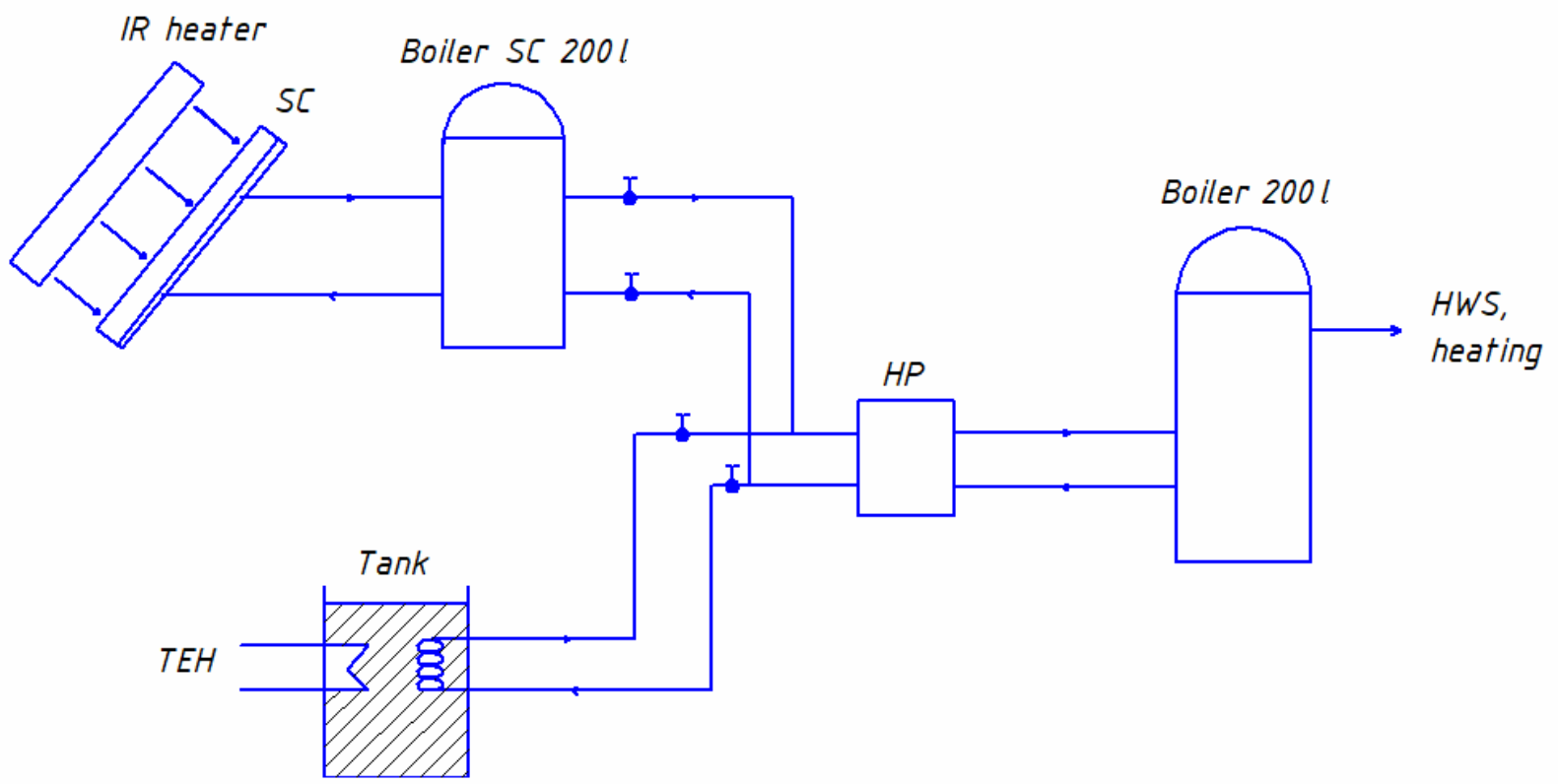

Fig. 3. Installation diagram with the inclusion of a heat pump, solar collector and tubular electric heater: IR heater - infrared heater; SC - solar collector; Tank - cubic tank with simulated wastewater; TEH - tubular electric heater; HP - heat pump; HWS - hot water supply.

${ }^{\circ} \mathrm{C}$. Also in this installation configuration (Figure 3) there will be no decrease in the water temperature due to heat exchange in the additional circuit of the tank, which was in the previous installation configuration (Figure 2).

Thus, the line "Infrared heater - solar collector boiler - heat pump - boiler - consumer HWS" - is the first line of this laboratory installation, operating on unconventional energy - solar energy.

The second line of the laboratory installation operates on simulated waste energy flows - wastewater and is a chain: "Tubular electric heater - bottom tank - heat pump - boiler - HWS user".

Consequently, the tank remains in the installation. But the source that heats the water in the tank is not the solar collector, but the tubular electric heater. In this case, both lines can operate simultaneously.

\section{Conclusions}

The calculation of the upgraded configuration of the laboratory unit with a heat pump at a temperature of the heat source of $38^{\circ} \mathrm{C}$ (table 2) was carried out. It can be seen that this laboratory installation can satisfy the need for hot water supply for the building body by $7 \%$ during the heating period and by $12 \%$ during the non-heating period, that is, provide several laboratory rooms with hot water.

Thus, the selected installation configuration (Figure 3) uses solar energy for use in the heat pump directly, and not just to simulate the heat of wastewater [8 - 10]. The heat of sewage is simulated by water in a bottom tank, heated by a tubular electric heater.

The presence of additional equipment in the form of a solar collector, connected directly to the heat pump through the buffer capacity, provides an increase the temperature of the coolant fed to the heat pump. This increases the efficiency of the heat pump, as well as extends its service life. The presence of a tubular electric heater immersed in the tank, will not only, if necessary, maintain the desired temperature of the water inside the tank, but also create 2 separate circuits that will allow to conduct visual experiments with the installation.

This installation with a heat pump can be used not only to meet the needs of hot water supply to buildings,

Table 2. Calculation results.

\begin{tabular}{|l|c|c|}
\hline \multicolumn{1}{|c|}{ Parameter } & Value & Unit of measurement \\
\hline $\begin{array}{l}\text { Heat flow to the hot water supply of the housing B of the KGEU } \\
\text { for the heating period }\end{array}$ & 35.77 & $\mathrm{~kW}$ \\
\hline $\begin{array}{l}\text { Heat flow to the hot water supply of building B of the KGEU for a } \\
\text { non-heating period }\end{array}$ & 22.89 & $\mathrm{~kW}$ \\
\hline Specific heat load of the heat pump evaporator & 150 & $\mathrm{~kJ} / \mathrm{kg}$ \\
\hline Specific heat load of the heat pump condenser & 209 & $\mathrm{~kJ} / \mathrm{kg}$ \\
\hline Heat pump heat conversion coefficient & 4.2 & - \\
\hline Thermal load of the solar collector & 2.73 & $\mathrm{~kW}$ \\
\hline
\end{tabular}


but also in a number of industries [11 - 15]: for the utilization of the wastewater heat, for the utilization of the intermediates products heat in petrochemical, food, pulp and paper enterprises, etc.

\section{References}

1. V.V.Getman, The use of heat pump installations for the utilization of the heat of secondary energy resources, Bull. of Kaz. Tech. Uni., 17(9), 233-236 (2014)

2. I.M. Kalnin, S.K. Leguenko, V.P. Protsenko, S.B. Pustovalov, I.A. Savitsky, Heat pump technology in solving large-scale heating problems using lowpotential heat of energy sources, 5, 25-30 (2009)

3. L.V. Plotnikova, E.E. Kostyleva, I.I. Chilikova, S.Y. Sitnikov, The use of heat pump installations as part of waste energy convertion complexes in the joint generation of electrical and thermal energy, IOP Conf. Series: Earth and Environmental Science, Int. Scientific Conf. "Efficient waste treatment - 2018", 012067 (2019)

4. A.M. Abitov, Kh.M. Senov, The feasibility of using heat pumps for heating and hot water supply of buildings, 3, 76-79 (2013)

5. X. Hao, J. Li, M.C. Loosdrecht, H. Jiang, R. Liu, Energy recovery from wastewater: Heat over organics, Wat. Res., 161, 74-77 (2019)

6. J. Pelda, S. Holler, Spatial distribution of the theoretical potential of waste heat from sewage, A statistical approach Energy, 180, 751-762 (2019)

7. V.V. Slesarenko, V.V. Knyazev, V.V. Wagner, I.V. Slesarenko, Prospects for the use of heat pumps for utilization of heat from urban wastewaters, En. Sav. and Wat. Tr., 3, 28-33 (2012)

8. J. Wang, S. Li, G. Zhang, Y. Yang, Performance investigation of a solar-assisted hybrid combined cooling, heating and power system based on energy, exergy, exergo-economic and exergoenvironmental analyses, 196, 227-241 (2019)

9. J. Cai, Z. Li, J. Ji, F. Zhou, Performance analysis of a novel air source hybrid solar assisted heat pump, 8, 1133-45 (2019)

10. S.N. Rabelo, T.F. Paulino, L. Machado, W. Duarte, Economic analysis and design optimization of a direct expansion solar assisted heat pump, 188, 164-174 (2019)

11. I.V. Kladov, A.S. Sedlov, A.Ya. Shelginsky, V.V. Galaktionov, Analysis of the efficiency of using open-type electric pump systems with electric drive in the production of phosphoric acid extraction, $\mathbf{6}$, 13-17 (2012)

12. A.Ya. Shelginsky, A.S. Malenkov, Cogeneration systems based on secondary energy resources vare in the production of mineral fertilizers, 7, 32-37 (2014)

13. G.A. Nosov, D.A. Popov, V.I. Belskaya, V.S. Zhiltsov, D.S. Yakovlev, T.G. Kairalieva, Analysis of the possibilities of using heat pumps during vacuum evaporation, F. Chem. Tech., 10(6), 64-70 (2015)
14. P. Gataric, B. Sirok, M. Hocevar, L. Novak, Modeling of heat pump tumble dryer energy consumption and drying time, Dry. Tech., 37(11), 1396-1404 (2019)

15. A. Yang, S. Jin, W. Shen, I.L. Chien, J. Ren, Investigation of energy-saving azeotropic dividing wall column to achieve cleaner production via heat exchanger network and heat pump technique, 234, 410-422 (2019) 